The Geneva Papers on Risk and Insurance, 20 (No. 77, October 1995) 495-500

\title{
Europe on Its Way to a Single Currency*
}

\author{
by Cees Maas**
}

\section{Introduction}

To introduce the subject, there are first three important points to make.

First: EMU is approaching. Hence, the private sector and in particular the financial sector should be preparing for it.

Second: Since the biggest uncertainties about Economic and Monetary Union and the introduction of the single currency are: when, whom and how, politicians should do everything they can to increase certainty and clarity. They should take the necessary and relevant decisions in time and communicate them clearly to the private sector. They should show their involvement in and commitment to the process towards one single currency and avoid giving contradictary messages.

Third: Although introducing the single currency in one big bang seems to be impossible, I am in favour of the biggest big bang possible. I am therefore strongly against the idea of stretching the introduction period over several years, which is very costly, and therefore undesirable.

These are the most important points this paper is dealing with.

\section{Some facts and figures; EMU is underway}

Let me first start to provide some facts and figures of the process towards one single currency.

The EMU and the single currency is receiving quite a lot of publicity. The European Commission has published a Green Paper on the introduction of the ECU as the single currency. At the same time a Progress Report has been published by the Expert Group on the changeover to the single currency. On the 26th and 27th of June, the European Council has met in Cannes. On that summit meeting of the heads of State and of Governments, the way towards EMU and the single currency is a substantial part of the agenda.

* Speech given on the occasion of the 22nd General Assembly of the Geneva Association, Lisbon, May 25, 1995.

** Chairman of the Expert Group on the changeover to the single currency and member of the Executive Board of ING Group. 
Why is the subject of EMU on the top of politicians agenda? Let's have a look on the timetable of the Treaty of Maastricht. The EMU was launched in December 1991, when the Maastricht Treaty was signed by all twelve Member States. The Treaty provides for the forming of an Economic and Monetary Union in 1997 with half of its member states or, if that is not possible, in 1999 at the latest. Key elements of EMU are a single currency, a single monetary policy, a single European Central Bank, a limitation of the autonomy of national governments to determine their own budget deficit and their own public debt, and an obligation of the Member States to converge their economic policies.

Before a country can go to the final stage of EMU it has to meet certain convergence criteria.

Sincc 1 January 1994, we are now in the second stage of the EMU process. A key element of the present stage is the existence of the so-called excessive deficit procedures and of the accompanying convergence programmes. At this stage, the trend in public finances in the Member States is being closely monitored by the European Commission. If a Member State fails to comply with the criteria set for the public deficit and the national public debt, then its deficit or debt is officialy labelled excessive. In that case the Member States concerned need to advance their convergence programmes to deal with these imbalances.

A second, key element of the present stage, is the existence of the European Monetary Institute, the EMI. The EMI basically has two tasks: The first task is to coordinate monetary policy. The second task is to make the necessary preparations for the new European Central Bank and for the single monetary policy and the single currency in the third stage. The EMI has therefore a preparatory task in the printing of the new ECU bank notes.

The European Commission, too, has an important role to play at the present second stage. The Commission and the EMI are required to prepare reports on the progress being made by Member States in their way to EMU. They have to do that for the first time in the first half of 1996. It is on the basis of these reports that the European Council will decide on July 1, 1996 at the latest if a majority of the member states is ready to go to the third stage. If so, the third stage will start on January 1, 1997. If at the middle of 1996 a majority of the member states does not meet the convergence criteria, the third stage will start on January 1, 1999, whether or not a majority of Member States is ready for it. Of course only those Member States that fulfil the convergence criteria will then participate. If that will really happen and who will participate, will be part of the unknown aspects on which I will come back later.

But the first decision whether or not to start EMU is only one year ahead! And some important aspects of the third stage of EMU are unknown and undecided yet. For example: A decision has not been made on the number of denominations of notes and coins, not on the size of notes and coins, the material, the design and the name!

The European Commission is also responsible for all other matters within its competence, which are necessary for a good and proper start of EMU.

One of these aspects is the smooth introduction of the single currency. The European Commission set up the "Expert Group on the changeover to the single currency" in May 1994 with the remit of advising the Commission on the technical preparations for a smooth introduction of the single currency into the European Union. The Group, under my chairmanship, consists of 14 (private) individuals, selected solely on the strength of their personal expertise and capabilities. They are bankers, industrialists, entrepreneurs from small 
and medium-sized companies, legal experts, communication experts, etc. The Expert Group completed an Interim Report which was presented to EU vice-president Mr. Christophersen on 26 January 1995.

In March and April the Expert Group held hearings with representatives of important sectors in the European economy, including consumers and financial institutions. Among the latter was a representative of the Comité Européen des Assurances in Brussels. In total we had 48 hearings in seven days.

The outcome of these hearings and their implications for the EMU process were the main subjects of a Progress Report which the Expert Group submitted to the European Commission at the beginning of June. As I told you before, it was published, in conjunction with the Green Paper of the European Commission, around the 31 May. Let me briefly give you the main topics. Our findings of the hearings were very interesting.

- There was a great lack of awareness.

- There was a great degree of uncertainty about "when" to start EMU, "who" should start and "how" to start.

- The single currency must be a strong and stable currency. This was seen as more important than the appearance of the currency.

- The introduction must not destabilise the financial markets and financial products. Therefore there was broad support for the introduction of an ECU-clause in financial contracts and for additional legal measures.

- A rapid introduction of notes and coins after the start of EMU was seen as essential. It was considered to be a crucial factor for the overall success of the changeover. Therefore, I favour the biggest bang possible.

\section{When will EMU start?}

So far I discussed some known aspects of the process towards EMU.

Let me briefly elaborate on some unknown aspects, that is on the future.

Let me do that along the lines of the uncertainties I just mentioned: when, who and how.

The first question is, when the third stage will start and the single currency be introduced. Will it happen in 1997 ? For a decision to be made at the middle of 1996, there is the requirement that a majority of Member States should obey the convergence criteria. Is there a chance? No, or just a very limited one.

Will it happen $1 / 1 / 99$ ? Yes, probably. Political circles already indicated that this is the most likely starting date. I think only Germany, France and 3-4 smaller countries will start by then. This brings me to the who question.

Nowadays, only two countries, Germany and Luxembourg, fulfil all the criteria.

Judgement will be made at the beginning of ' 98 on the basis of reports with figures of ' 97 ! That is only $2 \frac{1}{2}$ years from now! What is the position of the other potential countries, apart from Germany and Luxembourg?

In France, the budget deficit is far too high. There is also uncertainty about the new President's commitment to the EMU process. But: 1999 ... yes.

The Netherlands is still suffering from an overly high national debt.

Austria, the other country whose currency is closely pegged to the Deutschmark, is suffering from an overly high budget deficit. 
Belgium faces two problems: both its budget deficit and its national debt are too high.

The Irish, finally, are doing their best, but have the disadvantage of their currency being pegged to the pound sterling.

I did not mention the UK and Denmark, not so much because they will not meet the convergence criteria in time - both of them might be able to do so - but because of their political reservations.

\section{Convergence}

My provisional conclusion is that EMU will start on January 1, 1999 with Germany, France and 3 to 4 smaller countries: Luxembourg, Austria, the Netherlands, maybe Denmark, Ireland and maybe Belgium. Those countries can meet all the convergence criteria at the beginning of ' 98 .

I have already said a lot about convergence, but it is a very important point and regrettably not always rated at its true value, even by some well known economists. We feel that Europe should only start with a single currency if that currency is at least as strong as the strongest national currency.

Why? Only then the markets will accept it, because it is only then that the Germans will accept it. Interest rates can then be lower everywhere! And last but not least: we learned from the hearings too that the stability of the new currency is the most important thing from a consumer's point of view.

Therefore it is of utmost importance that countries strictly adhere to and stick to the convergence policies! The words and speeches of politicians are often fine, but their policies are not always in line with what they are saying.

The exceptions are Luxembourg and to a large extent Germany.

We, as Expert Group, have expressed ourselves explicitly on this subject. Not because it is in our mandate, but because it determines to a large extent the outcome of the process. It determines the speed of the process and it determines the credibility of the process. Therefore it determines the cost of the process! And the cost of the process will be paid to a large extent by the private sector.

\section{How should EMU be launched?}

Speaking about costs, I come to the how question: how should EMU be launched? How should the single currency be introduced? Should it be a big bang? A delayed big bang? A gradual introduction?

The Interim report of the Expert Group makes clear that a big bang - in which the single currency will be introduced in one day or a long week-end - is technically impossible. But it also makes clear that the introduction should take place as quickly as possible.

Recently, Ministers of Finance of the EU and Central Bank Governor outlined their first ideas on the start of the third stage:

a. They need about one year after the decision has been taken by the European Council to start the third stage and to decide which countries will participate, to prepare for the full operation of the European Central Bank. Hence, they have asked the European Council to decide at the latest by 1 January 1998 in order to comply with the Treaty and to set the launch for 1 January 1999 at the latest. In itself I agree with this. 
b. They feel that they can only start minting and printing the new notes and coins after the decision has been taken on which countries will participate. After that they need three to four years for the minting and printing. So, if it is decided at the beginning of 1998 to start EMU in 1999, then the new notes and coins can only be ready in 2001 or 2002. At the start of EMU, the new currency will then only be introduced within the central banks, in conducting the single monetary policy and for issuing new government bonds. Afterwards the private sector can spontaneously introduce the new currency for the purpose of non-cash transactions wherever it likes to do so.

What is the consequence of this scenario of EU Ministers of Finance and Central Bankers? I can say an awful lot, but I want to concentrate on one main disadvantage: the two to three year time period between the start of EMU and the introduction of new notes and coins is too long! It can raise doubts about the irreversibility of the process, therefore it can evoke speculation against participating currencies perceived to be weak and confront the private sector with confusion and additional costs, because of the dual existence of the national currency and the new common currency. It requires dual accounting systems for a very long period of time. It causes confusion among the public.

Summarizing: the scenario of the EU Ministers of Finance and Central Bankers is a very risky one and therefore a costly one.

This is why we, as Expert Group, are insisting on a quick introduction of notes and coins. This can be brought about by making all the necessary preparations before 1998, e.g. the name of the new currency, the design of notes and coins, the denominations and so on, and by making use of the worldwide production capacity for minting and printing, not just the capacity in the countries joining EMU from the outset. If necessary the minting and printing process should start before $1 / 1 / 1998$.

Finally: some words about the possibility and necessity for the private sector to prepare for the third stage.

\section{Technical preparations}

1. 1999 seems to be far, but it is not. It is only $3 \frac{1}{2}$ years from now!

We strongly feel that the private sector has to prepare for it!

Of course: when/who/how is still uncertain ... nevertheless. What can be done?

- Banks and other financial institutions, like insurance companies, have to prepare for changing their computer systems and their payment systems.

- The introduction of chip cards by banks can help to make at least one aspect of the changeover a little easier.

- Retailers have to prepare for changing their pricing, their cash registers etc.

- Vendor machines, parking meters etc. have to be changed and so on and so forth.

- On the communication front, the public has to be informed and educated. And that is not only a task of the Government! They are our clients!

- Financial markets have to prepare for the changeover.

2. Issuers of shares, bonds or insurance policy contracts could insert a warning in their contracts, prospectuses, etc., that the substitution of the national currency by the new single currency will not be a reason to terminate the contract, nor to change any parts of the contract apart from its denomination. This means, amongst other things, that in case of bonds the coupon rate will not be changed because of the changeover to the new currency, despite the fact that the market interest will probably change. 
My advice: Let's start with these preparations now, as much as possible.

But, of course, the fact that things can be done before we know all the ins and outs of the future monetary union, doesn't relieve politicians from the responsibility of creating more certainty as soon as possible.

\section{Concluding remarks}

My advice to the private sector is: prepare yourself for the change from your national currency into the single currency. If you do it well in advance, then the costs will be relatively low and have more the nature of an investment! If you wait too long the costs will bc higher.

The worst thing, of course, is for us - the private sector - to be taken by surprise! And having some experience of political decision-making on a national and European level, I know that unexpected decisions cannot be entirely precluded, on the contrary.

So the lesson of today for the private sector is the same as it was yesterday and as it will be tomorrow: you are solely responsible for your own future. Be prepared for the future. You can never start too early and you can easily start too late. 